\title{
Improved Spectrophotometric Determination of Bismuth (III) with Bromopyrogallol Red in Mixed Surfactants-Application to Waters and Veterinary Preparation
}

\author{
Najih H. Shekho \\ Enas S. Thunoon \\ Department of Chemistry \\ College of Science \\ Mosul University
}

(Received 14/5/2012;Accepted 10/9/2012)

\begin{abstract}
A simple and sensitive spectrophotometric method for the determination of trace amounts of bismuth is established. The method is based on the reaction of bismuth with bromopyrogallol red at $\mathrm{pH} 3$ in the presence of a mixture of cetylpyridinium chloride and triton X-100 surfactants to form a blue coloured complex which shows maximum absorbance

at $644 \mathrm{~nm}$. A plot of absorbance with bismuth concentration gives a straight line indicating that Beer's law has been obeyed over the range 3-150 $\mu \mathrm{g} / 25 \mathrm{ml}$, i.e., $0.12-6 \mathrm{ppm}$ with a molar absorptivity of $3.3 \times 10^{4} 1 . \mathrm{mol}^{-1} . \mathrm{cm}^{-1}$ and Sandell's sensitivity index of 0.006 $\mu \mathrm{g} . \mathrm{cm}^{-2}$. The interfering effect of a number of common captions and anions in the presence of comosite mixture ( $\mathrm{NaF}$ and tartaric acid) and ascorbic acid as masking agents has been studied. The effect of common excipients has also been examined. The method has been applied successfully to the determination of bismuth in water samples and a veterinary preparation.
\end{abstract}

Keywords: Bismuth, Bromopyrogallol Red, Mixed surfactants, Spectrophotometry.

تهسينطرقةطفية لقير البزموث (III) مع الكلثف بروبو بليروكاللو الحمر بوجود

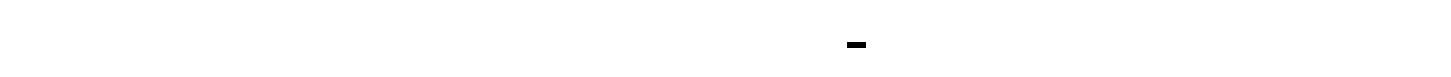

\section{الملذص}

قم تشبيتطريقة بسيطة ومسلسة لقدير كميت متناهية في الصغرمن البزموث. تعتمد الطريق ة عل ف

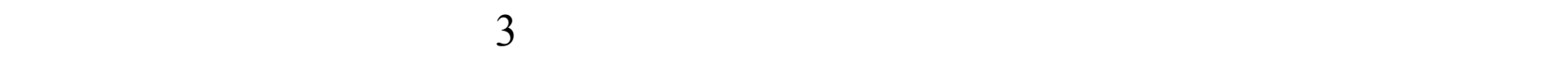

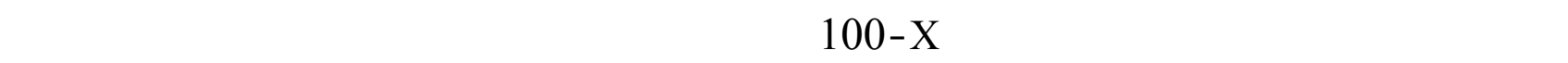

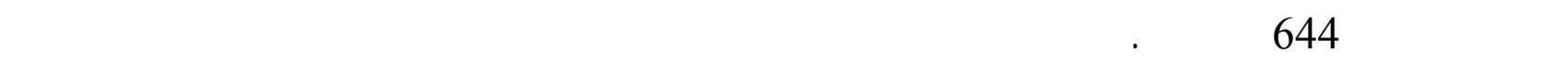

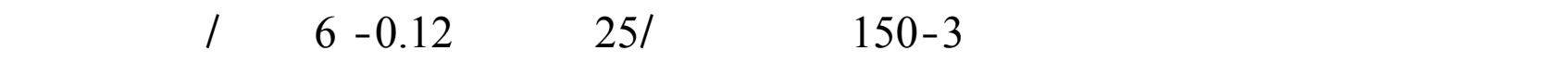




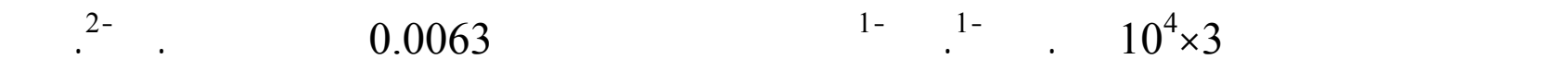

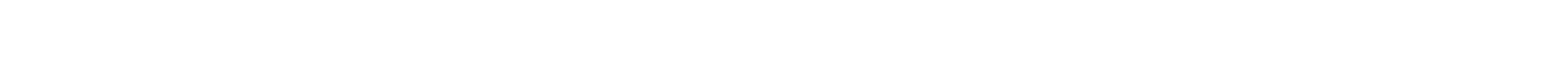

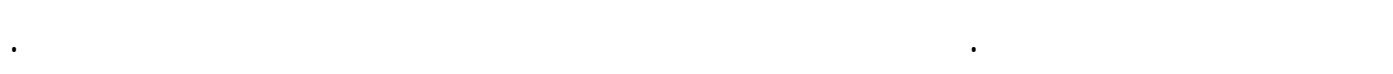

\section{INTRODUCTION}

Bismuth is found in the earth's crust up to $0.0002 \%$. It is least toxic among the heavy metals. Bismuth is used in the form of sub carbonates and sub gullets for the treatment of diarrhea, dysentery and ulcers, and also in the manufacture of low melting alloys, which find application in the fusible elements in automatic sprinklers, special solders, safety plugs in compressed gas cylinders and automatic shutoffs for gas and electric water heating system. (Gaikwad et al., 2005). Bismuth and its compounds are used in semiconductors, cosmetic preparations, alloys and metallurgical additives and in the preparation and recycling of uranium nuclear fuels(Thomas, 1991). Bismuth compounds are used orally in human and veterinary medicine for antiacidaction and mildly astringent action in gastrointestinal disorders, including diarrhea, flatulence and ulcerative gastritis and colitis (Demetrius et al., 2001). It has been used in peptic ulcer treatment and tropical dermatological cream. As the use of bismuth in medicine increased, it has spread in the environment and the chance of exposure of organisms to bismuth has been increased. A number of toxic effects in humans have been attributed to bismuth compounds, such as nephrotoxic, neurotoxic, kindeydamhage symptoms nephropthy, osteoarthrapathy, hepatitis and neuropathology (Afkami et al., 2006). Bismuth salts have emerged as efficient lewis acids due to their relatively low toxicity,therefore it used a catalyzed route for the synthesis of $\alpha$-aminophosphonates from aldehydes . (Banik et al., 2010). Bismuth salt (bismuth nitrate) is used for synthesis and characterization of compounds, using bismuth nitrate pentahydrate in THF adsorbed silica gel/fly ash under microwave method. (Badgjar et al., 2010). The development of analytical techniques for the determination of bismuth at low levels in aquatic sample is significant. So, analytical techniques such as spectrophotometry, flame atomic absorption spectrometry (FAAS), graphite furnace atomic absorption spectrometry (GFAAS) and inductively coupled plasma mass spectrometry (ICP-MS) have been used for its measurement (Oshita et al., 2007). The determination of bismuth in human plasma by ICP-MS and its use in bioequivalence studies has been reported (Shi et al., 2009). Gallacetophenone phenyl hydrazone (GPPH) has been used as an analytical reagent for amperometric determination of bismuth in wood's alloy (Reddy and Reddy., 2010). Several reagents have been used for the spectrophotometric determination of bismuth such as, dithiozone, diethyldithiocarbamate, xylenol orange, iodide, thiourea and azo reagents, (Marczenko, 2000). Kinetic spectrophotometric determination of $\mathrm{Bi}$ (III) has been employed, the method is based on using its catalytic effect on the oxidation of phenylfluorone by hydrogen peroxide in ammonia buffer, the method was confirmed by determining Bi (III) in a stomach ulcer drug (Rancic and Mandic, 2009). Extractive spectrophotometric determination of bismuth (III) in alloy samples using 1-amino-4, 4, 6trimethyl $(1 \mathrm{H}, 4 \mathrm{H})$ pyrimidine-2-thiol as an analytical reagent has also been reported (Gaikwad et al., 2005). 
The present work is devoted to the spectrophotometric study of the coloured complex of bismuth with bromopyrogallolred in the presence of mixture of cetylpyridinum chloride and Triton X-100 surfactants as an attempt to increase the sensitivity and selectivity of bismuth determination.

\section{EXPERIMENTAL}

Spectral and absorbance measurements are carried out using Shimadzu UV-Visible computerized double- beam spectrophotometer UV-160. In all measurements, $1-\mathrm{cm}$ matched cells are used. The $\mathrm{pH}$ measurements are carried out using (HANNA pH 211).

\section{Reagents}

All chemicals used are of highest purity available.

Stock bismuth (III) solution $(\mathbf{1 0 0 0} \mu \mathrm{g} / \mathrm{ml})$.

A stock solution is prepared by dissolving $0.2312 \mathrm{~g}$ of $\mathrm{Bi}\left(\mathrm{NO}_{3}\right)_{3 .} .5 \mathrm{H}_{2} \mathrm{O}$ (Fluka) in $3 \mathrm{ml}$ $5 \mathrm{M}$ nitric acid and diluting to the mark with distilled water in a $100 \mathrm{ml}$ volumetric flask. (Afkhami, 2006).

Working bismuth solution $(100 \mu \mathrm{g} / \mathrm{ml})$.

It is prepared by diluting $10 \mathrm{ml}$ of the stock solution to $100 \mathrm{ml}$ with distilled water in a volumetric flask.

Working bismuth solution $(10 \mu \mathrm{g} / \mathrm{ml})$.

It is prepared by diluting $10 \mathrm{ml}$ of the working solution $(100 \mu \mathrm{g} / \mathrm{ml})$ to $100 \mathrm{ml}$ withdistilled water in a volumetric flask.

Bromopyrogallol Red (BPR) reagent solution $\left(1 \times 10^{-3} \mathrm{M}\right)$.

It is prepared by dissolving $0.055 \mathrm{~g}$ of $\mathrm{BPR}(\mathrm{BDH})$ in distilled water and the solution is diluted to $100 \mathrm{ml}$ in a volumetric flask. The solution is transferred to a brown bottle where it remains stable for a least one week.

\section{Buffer solution pH 3}

It is prepared by mixing $50 \mathrm{ml}$ of $0.1 \mathrm{M}$ glycine solution with $5.7 \mathrm{ml}$ of $0.2 \mathrm{M} \mathrm{HCl}$ solution and diluting the volume to $100 \mathrm{ml}$ with distilled water in a volumetric flask, (Perrin and Dempsey, 1974).

\section{Cetylpyridinium chloride (CPC) solution $\left(2 \times 10^{-3} \mathrm{M}\right)$}

It is prepared by dissolving $0.179 \mathrm{~g}$ of CPC monohydrate (Fluka) in distilled water and the solution is diluted to $250 \mathrm{ml}$ in a volumetric flask.

\section{Triton X-100 solution (4\%)}

This solution is prepared by diluting $4 \mathrm{ml}$ of Triton X-100 (Scharlau) with hot distilled water and the solution is diluted to $100 \mathrm{ml}$ in a volumetric flask.

\section{Mixed complexing solution}

This solution is prepared by dissolving $0.3 \mathrm{~g}$ of tartaric acid (BDH) with $0.042 \mathrm{~g}$ of sodium fluoride) (BDH) in about $80 \mathrm{ml}$ distilled water. The $\mathrm{pH}$ of the resulting mixture is adjusted to 3 with $0.1 \mathrm{M} \mathrm{HNO}_{3}$ solution and the volume is then completed to $100 \mathrm{ml}$ with distilled water.

\section{Ascorbic acid solution (0.01M)}

It is prepared by dissolving $0.1761 \mathrm{~g}$ of ascorbic acid $(\mathrm{BDH})$ in distilled water. The $\mathrm{pH}$ of the solution is adjusted to 3 with nitric acid solution and the volume is completed to 100 $\mathrm{ml}$ with distilled water. 


\section{Veterinary preparation solution $(1000 \mu \mathrm{g} / \mathrm{ml})$}

The content of 6 sachets of Diaclean containing $2000 \mathrm{mg}$ bismuth subnitrate was weighed. A quantity of powder containing $0.1 \mathrm{mg} \mathrm{Bi}^{3+}$ is then dissolved in $5 \mathrm{ml}$ of $5 \mathrm{M}$ nitric acid and sufficient amount of distilled water. The solution is shaken thoroughly and then filtered. The filtrate was made up to $100 \mathrm{ml}$ with distilled water in a volumetric flask. The tested solution is prepared by an appropriate dilution.

\section{RESULTS AND DISCUSSION}

Preliminary studies of the reaction of bismuth (III) with BPR reagent indicate that the reaction proceed immediately after mixing. The violet coloured complex showed an absorption maximum at $597 \mathrm{~nm}$ in contrast to the reagent blank which shows maximum absorption at $522 \mathrm{~nm}$.

\section{Study of the optimum reaction conditions}

The effects of various parameters on the absorption intensity of the coloured complex are studied and the reaction conditions are optimised.

\section{Effect of pH}

The effect of $\mathrm{pH}$ on the colour intensity of the complex is studied with solutions containing $100 \mu \mathrm{g}$ of Bismuth (III) and various volumes of $0.01 \mathrm{M} \mathrm{HNO}_{3}$ and $\mathrm{NaOH}$ solutions and $2 \mathrm{ml}$ of $\left(1 \times 10^{-3} \mathrm{M}\right)$ BPR reagent and the volume is completed to $25 \mathrm{ml}$ with distilled water. The absorbance of each coloured solution against its corresponding blank solution and the final $\mathrm{pH}$ of the reaction mixtures are both measured. The results indicate that the absorbance is $\mathrm{pH}$ dependent, and the maximum absorbance occurred at $\mathrm{pH} 3$ with maximum wavelength $602 \mathrm{~nm}$, therefore it is selected for subsequent experiments.

\section{Effect of buffers}

A series of various buffer solutions of $\mathrm{pH} 3$ are prepared and their effects on the absorbance, $\lambda_{\max }$ and the $\mathrm{pH}$ of the final reaction mixture are examined. Seven buffer solutions of $\mathrm{pH} 3$ such as tartaric acid- $\mathrm{NaOH}\left(\mathrm{B}_{1}\right)$, citric acid- $\mathrm{NaOH}\left(\mathrm{B}_{2}\right)$, khphalate $-\mathrm{HCl}$ $\left(\mathrm{B}_{3}\right)$, glycine - $\mathrm{HCl}\left(\mathrm{B}_{4}\right)$ citric acid -sod. citrate $\left(\mathrm{B}_{5}\right)$,acetic acid - sodium acetate $\left(\mathrm{B}_{6}\right)$ and succinic acid $-\mathrm{NaOH}\left(\mathrm{B}_{7}\right)$, (Perrin and Dempsey, 1974) are tested for the purpose. The results are given in Table (1).

Table 1: Effect of buffers.

\begin{tabular}{|c|c|c|c|c|c|c|c|}
\hline \multirow{2}{*}{$\begin{array}{c}\text { ml of Buffer } \\
\text { solution }\end{array}$} & \multicolumn{7}{|c|}{ Absorbance/ml of Buffer added } \\
\cline { 2 - 8 } & $\mathbf{B}_{\mathbf{1}}$ & $\mathbf{B}_{\mathbf{2}}$ & $\mathbf{B}_{\mathbf{3}}$ & $\mathbf{B}_{\mathbf{4}}$ & $\mathbf{B}_{\mathbf{5}}$ & $\mathbf{B}_{\mathbf{6}}$ & $\mathbf{B}_{\mathbf{7}}$ \\
\hline 1.0 & 0.034 & 0.037 & 0.090 & 0.138 & 0.070 & 0.106 & 0.099 \\
\hline 2.0 & 0.025 & 0.036 & 0.088 & 0.164 & 0.058 & 0.123 & 0.096 \\
\hline 3.0 & 0.022 & 0.032 & 0.099 & 0.158 & 0.045 & 0.121 & 0.094 \\
\hline 4.0 & 0.020 & 0.027 & 0.078 & 0.151 & 0.061 & 0.118 & 0.092 \\
\hline 5.0 & 0.018 & 0.021 & 0.073 & 0.148 & 0.035 & 0.114 & 0.083 \\
\hline 6.0 & 0.015 & 0.019 & 0.071 & 0.145 & 0.031 & 0.112 & 0.085 \\
\hline 7.0 & 0.011 & 0.014 & 0.065 & 0.142 & 0.029 & 0.113 & 0.082 \\
\hline$\lambda$ max (nm) & $565-585$ & $551-571$ & $550-570$ & $593-608$ & $597-569$ & $600-587$ & $603-596$ \\
\hline $\begin{array}{c}\text { Final pH of } \\
\text { the reaction } \\
\text { mixture }\end{array}$ & $3.3-3.1$ & $3.29-3.27$ & $3.3-3.0$ & $3.3-3.0$ & $3.2-3.1$ & $3.3-3.6$ & $3.5-3.7$ \\
\hline
\end{tabular}


It can be noticed in Table (1) that buffer solution $\left(\mathrm{B}_{4}\right)$ is only useful from the analytical point of view. The other buffers show an un-encouraging results. For the subsequent work, a $2 \mathrm{ml}$ of buffer $\left(\mathrm{B}_{4}\right)$ solution has been chosen because it gives the highest sensitivity and good colour contrast.

\section{Effect of surfactants}

The effect of the presence of cationic (Cetylpyridinium chloride, CPC, Cetyltrimethylammonium bromide, CTAB), anionic (Sodium dodecyl sulphate, SDS) and non- ionic (Iso-octylphenoxypolyethoxy ethanol, Triton X-100) surfactants on the colour intensity of the complex is examined with different orders of addition. The results are shown in Table (2).

Table 2: Effect of surfactants.

\begin{tabular}{|c|c|c|c|c|c|c|c|c|}
\hline $\begin{array}{c}\text { Surfactant } \\
\text { solution (3mI) }\end{array}$ & \multicolumn{5}{|c|}{ Absorbance*/order of addition** } & \multirow{2}{*}{$\boldsymbol{\lambda}_{\max }(\mathbf{n m})$} & $\begin{array}{c}\Delta \boldsymbol{\lambda} \\
(\mathbf{n m})\end{array}$ \\
\cline { 2 - 8 } $\mathrm{CPC} 1 \times 10^{-3} \mathrm{M}$ & 0.255 & 0.296 & 0.249 & 0.252 & $\begin{array}{c}0.23 \\
1\end{array}$ & 0.180 & 638 & 72 \\
\hline $\mathrm{CTAB} 1 \times 10^{-3} \mathrm{M}$ & 0.181 & 0.167 & 0.207 & 0.201 & $\begin{array}{c}0.19 \\
0\end{array}$ & 0.184 & 634 & 57 \\
\hline $\mathrm{SDS} 1 \times 10^{-3} \mathrm{M}$ & 0.144 & 0.115 & 0.093 & 0.105 & $\begin{array}{c}0.19 \\
3\end{array}$ & 0.149 & 607 & 70 \\
\hline $\begin{array}{c}\text { Triton X-100 } 1 \% \\
(\mathrm{v} / \mathrm{v})\end{array}$ & 0.183 & 0.204 & 0.204 & 0.193 & $\begin{array}{c}0.18 \\
4\end{array}$ & 0.120 & 582 & 50 \\
\hline
\end{tabular}

* Absorbance without surfactant $=0.162$

** $\mathrm{I}=$ Bismuth ion $(\mathrm{M})+\mathrm{B}$ (Buffer) $+\mathrm{R}$ (Reagent BPR) $+\mathrm{S}$ (Surfactant) .

$\mathrm{II}=\mathrm{M}+\mathrm{S}+\mathrm{R}+\mathrm{B}$

$\mathrm{III}=\mathrm{M}+\mathrm{B}+\mathrm{S}+\mathrm{R}$

$\mathrm{IV}=\mathrm{M}+\mathrm{S}+\mathrm{B}+\mathrm{R}$

$\mathrm{V}=\mathrm{M}+\mathrm{R}+\mathrm{B}+\mathrm{S}$

$\mathrm{VI}=\mathrm{M}+\mathrm{R}+\mathrm{S}+\mathrm{B}$

The results in Table (2) indicate that CPC solution causes bathochromic shift and increasing in the intensity of absorbance of formed complex with order of addition No.(II). Therefore the effect of different volumes of higher concentration of CPC $\left(2 \times 10^{-3} \mathrm{M}\right)$ on the intensity of coloured complex has been studied [Table (3)].

Table 3: Effect of CPC amount.

\begin{tabular}{|c|c|c|c|}
\hline $\begin{array}{c}\text { ml of 2×10 } \\
\text { M CPC }\end{array}$ & Sample & $\lambda_{\text {max }}$ (nm) & Blank \\
\hline 1 & 0.223 & 631 & 0.070 \\
\hline 2 & 0.252 & 635 & 0.056 \\
\hline 3 & 0.324 & 635 & 0.060 \\
\hline 4 & 0.331 & 636 & 0.054 \\
\hline 5 & 0.288 & 633 & 0.057 \\
\hline
\end{tabular}


The results obtained in Table (3) indicate that the addition of $4 \mathrm{ml}$ of CPC with order No. (II) [Table (2)] gives maximum absorbance and the lowest blank value, so it has been used in the subsequent experiments.

\section{Effect of mixed surfactants and temperature}

It is found that the presence of $4 \%$ Triton X-100 solution with $2 \times 10^{-3} \mathrm{M} \mathrm{CPC}$ in the reaction mixture, an increase in the absorbance of the coloured complex is observed obviously especially when the reaction mixture is heated. The effect of temperature on the absorbance of the coloured complex is shown in Table (4).

Table 4: Effect of temperature.

\begin{tabular}{|c|c|c|c|}
\hline Temperature $\left({ }^{\circ} \mathbf{c}\right)$ & Absorbance* $^{*}$ & $\boldsymbol{\lambda} \mathbf{( n m )}$ & $\Delta \boldsymbol{\lambda} \mathbf{( n m )}$ \\
\hline 20 & 0.208 & 630 & 97 \\
\hline 30 & 0.331 & 636 & 103 \\
\hline 40 & 0.496 & 639 & 106 \\
\hline 45 & 0.556 & 640 & 107 \\
\hline 50 & 0.592 & 644 & 111 \\
\hline 55 & 0.590 & 644 & 99 \\
\hline
\end{tabular}

*Using $1 \mathrm{ml}$ of Triton $\mathrm{X}-100$

From the results in Table 4, it is observed that maximum absorbance and a good colour contrast are obtained at $50 \mathrm{C}^{\circ}$. The effect of heating time on the absorbance of the coloured complex is then studied and the experimental results showed that a heating time of 5-7 min, was enough for the completion of the reaction.

\section{Effect of the amount of Triton X-100}

The effect of different volumes of $4 \%$ Triton X-100 on the intensity of the formed complex has next been studied. The experimental results showed that $1 \mathrm{ml}$ of $4 \%$ Triton X100 was optimum.

\section{Effect of reagent amount}

Different volumes of $1 \times 10^{-3} \mathrm{M}$ BPR solution are added to $10-125 \mu \mathrm{g}$ of bismuth while other conditions being kept constant. A $2 \mathrm{ml}$ of the reagent solution has been found to be optimum volume since the linearity (correlation coefficient) is good and the sensitivity of the colour reaction is fair.

\section{Effect of masking agents}

The presence of tartaric acid, $\mathrm{NaF}$ and ascorbic acid in the reaction mixture is essential because they increase the selectivity of the method by masking cations from their reactions with BPR. Other complexons such as EDTA, EGTA and NTA decrease the absorbance owing to their complexons action with bismuth. Therefore, a composite masking solution has been prepared containing $0.01 \mathrm{M} \mathrm{NaF}$ and $0.02 \mathrm{M}$ tartaric acid. Since the solution of ascorbic acid is unstable, it is added separately. The effect of composite complexing solution (with different volumes of $0.01 \mathrm{M}$ ascorbic acid) on the absorbance of coloured complex is examined. The results are given in Table (5) 
Table 5: Effect of composite mixture with different volumes of ascorbic acid.

\begin{tabular}{|c|c|c|c|c|}
\hline \multirow{2}{*}{$\begin{array}{c}\text { Amount of composite } \\
\text { complexing solution }\end{array}$} & \multicolumn{4}{|c|}{ Absorbance/ml of (0.01 M) ascorbic acid } \\
\cline { 2 - 5 }$(\mathbf{m l})$ & $\mathbf{0}$ & $\mathbf{1}$ & $\mathbf{2}$ & $\mathbf{3}$ \\
\hline 1 & 0.587 & 0.589 & 0.603 & 0.601 \\
\hline 2 & 0.623 & 0.635 & 0.645 & 0.615 \\
\hline 3 & 0.569 & 0.544 & 0.533 & 0.516 \\
\hline 4 & 0.551 & 0.536 & 0.534 & 0.533 \\
\hline 5 & 0.511 & 0.496 & 0.452 & 0.432 \\
\hline
\end{tabular}

The results indicate that $2 \mathrm{ml}$ of both mixed complexing solution and ascorbic acid are desired for subsequent experiments because of the highest sensitivity.

\section{Effect of order addition}

The orders of addition of solution are examined and the results are shown in Table (6)

Table 6 : Effect of order addition.

\begin{tabular}{|c|c|c|}
\hline Reaction components* & Order number & Absorbance \\
\hline $\mathrm{M}+\mathrm{CM}+\mathrm{AA}+\mathrm{S}_{1}+\mathrm{S}_{2}+\mathrm{R}+\mathrm{B}$ & $\mathrm{I}$ & 0.578 \\
\hline $\mathrm{M}+\mathrm{CM}+\mathrm{AA}+\mathrm{B}+\mathrm{S}_{1}+\mathrm{S}_{2}+\mathrm{R}$ & II & 0.653 \\
\hline $\mathrm{M}+\mathrm{B}+\mathrm{S}_{1}+\mathrm{S}_{2}+\mathrm{CM}+\mathrm{AA}+\mathrm{R}$ & III & 0.073 \\
\hline $\mathrm{M}+\mathrm{S}_{1}+\mathrm{S}_{2}+\mathrm{B}+\mathrm{CM}+\mathrm{AA}+\mathrm{R}$ & $\mathrm{IV}$ & 0.545 \\
\hline $\mathrm{M}+\mathrm{B}+\mathrm{R}+\mathrm{CM}+\mathrm{AA}+\mathrm{S}_{1}+\mathrm{S}_{2}$ & V & 0.079 \\
\hline $\mathrm{M}+\mathrm{B}+\mathrm{CM}+\mathrm{AA}+\mathrm{R}+\mathrm{S}_{1}+\mathrm{S}_{2}$ & VI & 0.137 \\
\hline $\mathrm{M}+\mathrm{R}+\mathrm{CM}+\mathrm{AA}+\mathrm{B}+\mathrm{S}_{1}+\mathrm{S}_{2}$ & VII & 0.474 \\
\hline $\mathrm{M}+\mathrm{S}_{1}+\mathrm{S}_{2}+\mathrm{CM}+\mathrm{AA}+\mathrm{B}+\mathrm{R}$ & VIII & 0.528 \\
\hline
\end{tabular}

*Bismuth (M) ,buffer solution (B), CPC $\left(\mathrm{S}_{1}\right)$, Triton X-100 $\left(\mathrm{S}_{2}\right)$, BPR reagent(R), $\mathrm{CM}=$ Composite mixture, $\mathrm{AA}=$ Ascorbic acid.

From the results above, order (II) has been used for a subsequent experiment, due to the highest sensitivity.

\section{Effect of time}

A study of the time effect on the absorbance of the final reaction mixture shows that the maximum absorbance is obtained after 20 minutes and remains stable for at least 1 hour.

\section{Final absorption spectra}

Under the above established conditions, absorption spectra of a blue complex of bismuth-BPR-CPC-Triton X-100 and of its reagent blank are recorded and are shown in Fig. (1). The coloured complex exhibits maximum absorbance at $644 \mathrm{~nm}$ in contrast with the reagent blank which shows maximum absorbance at $533 \mathrm{~nm}$. 


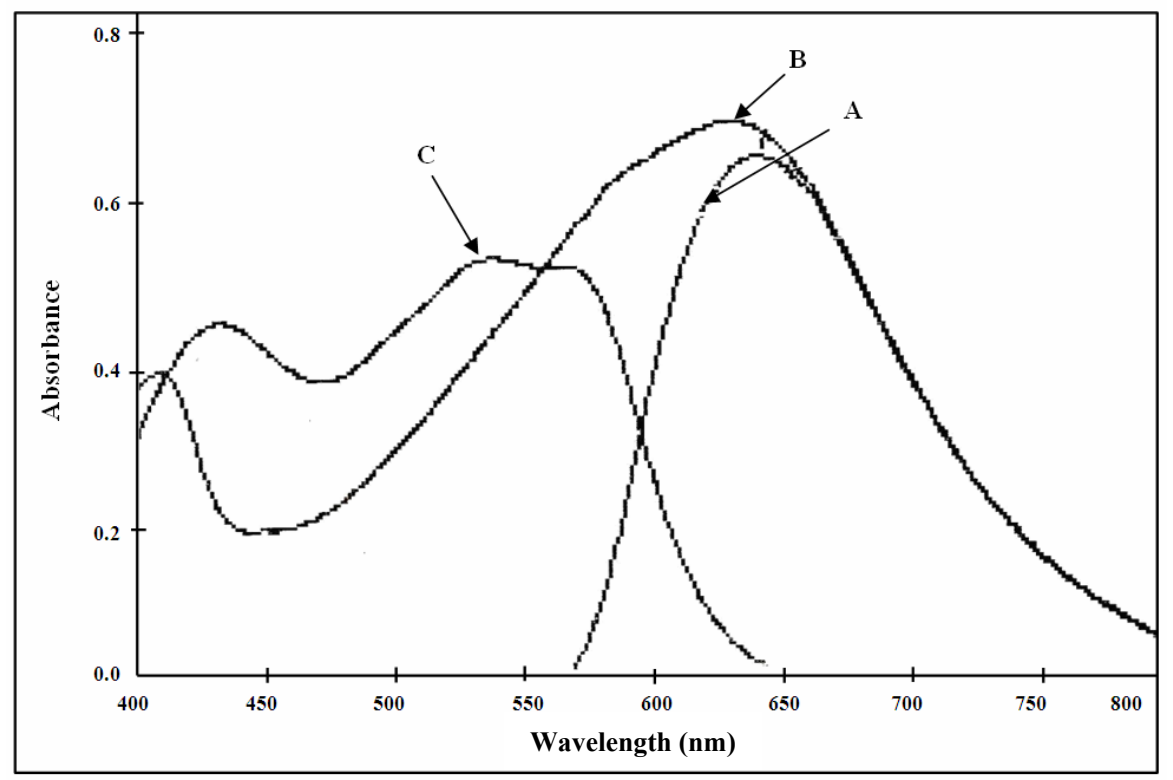

Fig. 1: Absorption spectra of $100 \mu \mathrm{g}$ Bi (III) $/ 25 \mathrm{ml}$ measured against (A) blank, (B) distilled water and (C) blank against distilled water.

\section{Recommended procedure and calibration Graph}

Sample aliquots containing 3-250 $\mu \mathrm{g}$ of bismuth solution are placed into $25-\mathrm{ml}$ volumetric flasks. To each bismuth solution, $2 \mathrm{ml}$ of mixed complex solution $(0.01 \mathrm{M} \mathrm{NaF}$ and $0.02 \mathrm{M}$ tartaric acid), $2 \mathrm{ml}$ of $0.01 \mathrm{M}$ ascorbic acid, $2 \mathrm{ml}$ of buffer $\mathrm{pH} 3,4 \mathrm{ml}$ of $2 \times 10^{-3} \mathrm{M}$ CPC, $1 \mathrm{ml}$ of $4 \%$ Triton $\mathrm{X}-100$, and $2 \mathrm{ml}$ of $1 \times 10^{-3} \mathrm{M}$ BPR are added. The solution is mixed and diluted to the mark with distilled water and heated to $50 \mathrm{C}^{\circ}$ for about 5 min in water bath. After about $10 \mathrm{~min}$, the absorbance of each coloured solution at $644 \mathrm{~nm}$ is measured against the reagent blank, prepared in the same manner but without bismuth. Beer 's law is obeyed within the range (3-150) $\mu \mathrm{g}$ of $\mathrm{Bi}$ (III) in a final volume of $25 \mathrm{ml}$ (i.e., 0.12-6 ppm) [Fig. (2)]. The molar absorptivity and Sandell's sensitivity are $3.3 \times 10^{4} 1 . \mathrm{mol}^{-1} \cdot \mathrm{cm}^{-1}$ and 0.006 $\mu \mathrm{g} . \mathrm{cm}^{-2}$, respectively.

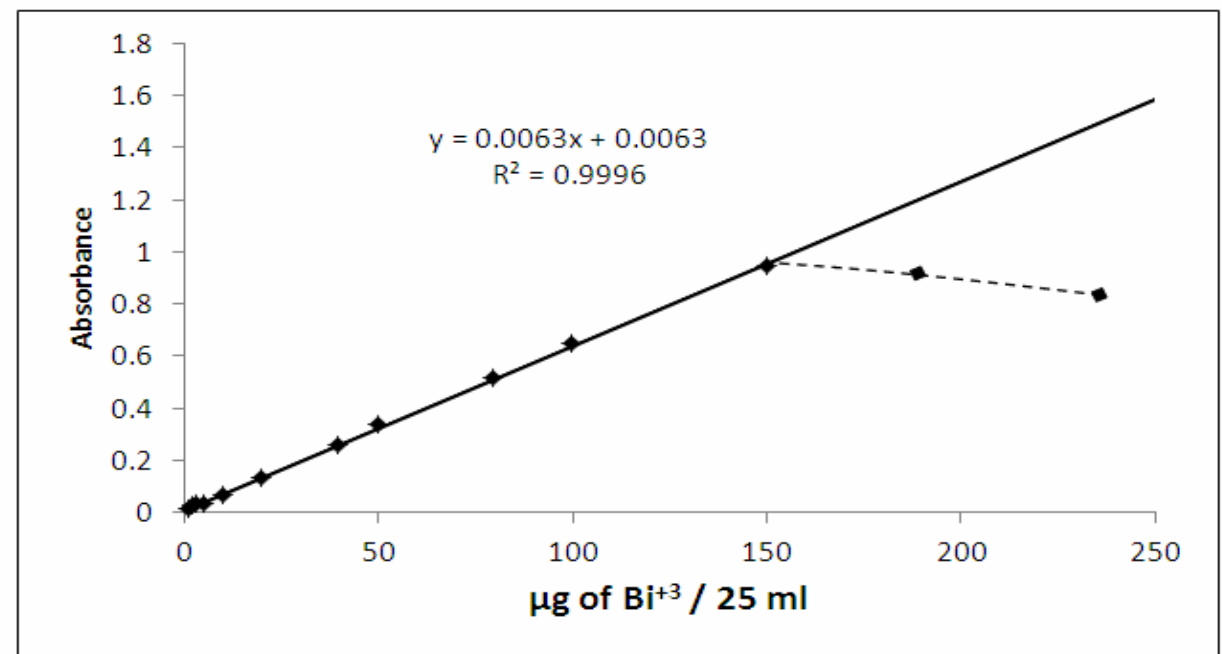

Fig. 2: Calibration graph for $\mathrm{Bi}^{3+}$ determination using the proposed method. 


\section{Accuracy and precision}

To check the accuracy and precision of the cribration graph, bismuth (III) is determined at three different concentrations. The results shown in Table (7) indicate that the method is satisfactory.

Table 7: Accuracy and precision.

\begin{tabular}{|c|c|c|}
\hline $\begin{array}{c}\text { Amount of bismuth } \\
\text { taken, } \boldsymbol{\mu g}\end{array}$ & $\begin{array}{c}\text { Recovery* } \\
\text { (\%) }\end{array}$ & RSD (\%) \\
\hline 25 & 100.5 & \pm 0.543 \\
\hline 50 & 98.03 & \pm 1.752 \\
\hline 100 & 99.9 & \pm 0.398 \\
\hline
\end{tabular}

*Average of five determinations.

\section{Nature of the complex}

The stoichiometry of the complex has been studied by both Job's method of continuous variations and mole-ratio method (Delevie, 1997). The results reveal that the combination ratio of bismuth (III) with BPR is $(1: 2)$. Both methods are used to study the proportion of $\mathrm{CPC}$ in the complex and the results obtained do not give the expected proportion, as the colour of the solution changes with the addition of different amounts of CPC. The average of the stability constant of the coloured complex is found to be $\left(4.3 \times 10^{11}\right) \mathrm{M}^{-2}$ (Hargis, 1988). The empirical formula of the chelate can be written as follows.

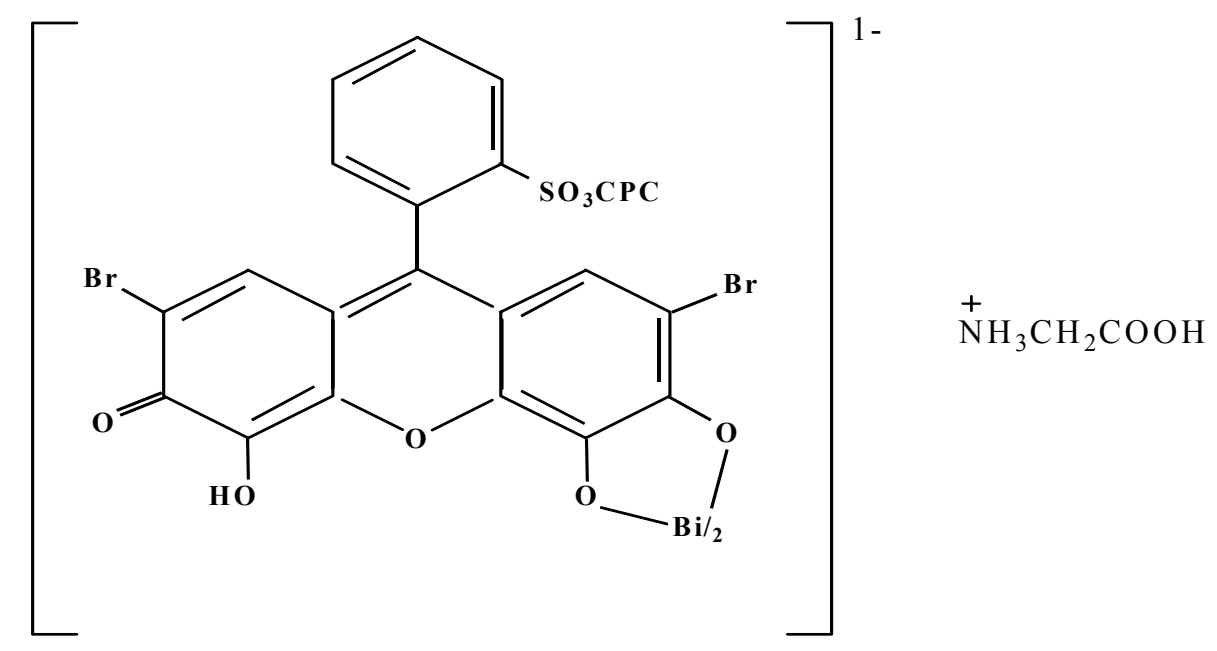

\section{Bi(III)-Bromopyrogallol Red-CPC Complex}

\section{Effect of Interference}

The influence of diverse ions on the determination of bismuth is examined under the conditions of standard procedure. The diverse ions are added, individually, to solutions containing $100 \mu \mathrm{g}$ of bismuth. The results are summarised in Table (8), from which it can be concluded that the method seems to be selective except towards $\mathrm{Al}^{3+}, \mathrm{Fe}^{2+}, \mathrm{Mn}^{2+}, \mathrm{Ni}^{2+}$ and $\mathrm{Zr}^{4+}$ ions. 
Table 8: Effect of interference (1).

\begin{tabular}{|c|c|c|c|c|}
\hline \multirow{2}{*}{ Foreign ion } & \multirow{2}{*}{ Form added } & \multicolumn{3}{|c|}{ Error $\% / \mu \mathrm{g}$ of interference added } \\
\hline & & 50 & 100 & 300 \\
\hline $\mathrm{Al}^{3+}$ & $\mathrm{AlCl}_{3} \cdot 6 \mathrm{H}_{2} \mathrm{O}$ & -49.3 & -66.46 & -70.12 \\
\hline $\mathrm{Ag}^{+}$ & $\mathrm{AgNO}_{3}$ & -2.81 & -4.21 & -3.12 \\
\hline $\mathrm{Ba}^{2+}$ & $\mathrm{BaCl}_{2} \cdot 2 \mathrm{H}_{2} \mathrm{O}$ & 0.91 & -4.42 & -14.32 \\
\hline $\mathrm{Be}^{2+}$ & $\mathrm{BeSO}_{4} \cdot 4 \mathrm{H}_{2} \mathrm{O}$ & +2.51 & +3.31 & 3.29 \\
\hline $\mathrm{Ca}^{2+}$ & $\mathrm{Ca}\left(\mathrm{NO}_{3}\right)_{2}$ & -2.5 & -3.2 & -4.5 \\
\hline $\mathrm{Cd}^{2+}$ & $\mathrm{Cd}(\mathrm{CH} 3 \mathrm{COO})_{2} \cdot \mathrm{H}_{2} \mathrm{O}$ & -3.6 & -2.43 & +1.22 \\
\hline $\mathrm{Co}^{2+}$ & $\mathrm{Co}\left(\mathrm{NO}_{3}\right)_{2} \cdot 6 \mathrm{H}_{2} \mathrm{O}$ & -0.30 & -2.91 & -3.31 \\
\hline $\mathrm{Cs}_{2}$ & $\mathrm{CS}_{2} \mathrm{CrO}_{4}$ & $\begin{array}{l}+1.3 \\
\end{array}$ & +2.13 & $5.0+$ \\
\hline $\mathrm{Cu}^{2+}$ & $\mathrm{CuCl}_{2}$ & +0.150 & +0.60 & +0.91 \\
\hline $\mathrm{Fe}^{2+}$ & $\mathrm{FeSO}_{4}\left(\mathrm{NH}_{4}\right)_{2} \mathrm{SO}_{4} \cdot 6 \mathrm{H}_{2} \mathrm{O}$ & -14.7 & -34.4 & -50.76 \\
\hline $\mathrm{Fe}^{3+*}$ & $\mathrm{Fe}\left(\mathrm{NO}_{3}\right)_{3} .9 \mathrm{H}_{2} \mathrm{O}$ & 0.30 & -3.20 & -3.81 \\
\hline $\mathrm{Hg}^{2+}$ & $\mathrm{Hg}\left(\mathrm{NO}_{3}\right)_{2}$ & 0.0 & -0.15 & $2.3+$ \\
\hline $\mathrm{K}^{+}$ & $\mathrm{KBr}$ & +0.15 & -2.83 & -4.44 \\
\hline $\mathrm{Mg}^{2+}$ & $\mathrm{MgCl}_{2} \cdot 6 \mathrm{H}_{2} \mathrm{O}$ & -0.59 & -0.45 & +2.39 \\
\hline $\mathrm{Mn}^{2+}$ & $\mathrm{MnCl}_{2}$ & -39.6 & -57.62 & -66.76 \\
\hline $\mathrm{Na}^{+}$ & $\mathrm{NaCl}$ & +0.14 & +0.25 & $0.37+$ \\
\hline $\mathrm{Ni}^{2+}$ & $\mathrm{Ni}\left(\mathrm{NO}_{3}\right)_{2} \cdot 6 \mathrm{H}_{2} \mathrm{O}$ & -84.75 & -87.80 & 89.93- \\
\hline $\mathrm{Pb}^{2+}$ & $\mathrm{Pb}\left(\mathrm{NO}_{3}\right)_{2}$ & -3.20 & -4.11 & -4.50 \\
\hline $\mathrm{Zn}^{2+}$ & $\mathrm{Zn}(\mathrm{Ac})_{2} .2 \mathrm{H}_{2} \mathrm{O}$ & +2.59 & $3.81+$ & +4.42 \\
\hline $\mathrm{Zr}^{4+}$ & $\mathrm{ZrOCl}_{2} .8 \mathrm{H}_{2} \mathrm{O}$ & -35.21 & -39.02 & -64.02 \\
\hline $\mathrm{Br}^{-}$ & $\mathrm{KBr}$ & +0.15 & -3.65 & -4.72 \\
\hline $\mathrm{Se}^{4+}$ & $\mathrm{SeO}_{2}$ & +1.98 & -1.06 & -1.82 \\
\hline $\mathrm{S}_{2} \mathrm{O}_{3}{ }^{2-}$ & $\mathrm{Na}_{2} \mathrm{~S}_{2} \mathrm{O}_{3} .5 \mathrm{H}_{2} \mathrm{O}$ & -2.61 & -3.21 & -3.86 \\
\hline $\mathrm{SO}_{3}{ }^{2-}$ & $\mathrm{Na}_{2} \mathrm{SO}_{3}$ & +3.72 & +4.58 & +5.02 \\
\hline $\mathrm{SO}_{4}{ }^{2-}$ & $\mathrm{Na}_{2} \mathrm{SO}_{4}$ & +3.21 & +3.42 & +4.35 \\
\hline $\mathrm{CO}_{3}{ }^{2-}$ & $\mathrm{Na}_{2} \mathrm{CO}_{3}$ & +2.51 & +3.25 & +4.26 \\
\hline $\mathrm{HCO}^{3-}$ & $\mathrm{NaHCO}_{3}$ & -2.13 & -2.59 & -3.20 \\
\hline $\mathrm{NO}_{2}^{2-}$ & $\mathrm{NaNO}_{2}$ & -1.37 & -2.82 & -3.65 \\
\hline $\mathrm{PO}_{4}{ }^{3-}$ & $\mathrm{NaH}_{2} \mathrm{PO}_{4} \cdot 2 \mathrm{H}_{2} \mathrm{O}$ & +2.59 & $\begin{array}{r}+0.152 \\
\end{array}$ & -3.50 \\
\hline $\mathrm{BO}_{3}{ }^{3-}$ & $\mathrm{H}_{3} \mathrm{BO}_{3}$ & +0.91 & -3.20 & -4.72 \\
\hline $\mathrm{C}_{2} \mathrm{O}_{4}{ }^{2-}$ & $\mathrm{Na}_{2} \mathrm{C}_{2} \mathrm{O}_{4}$ & +0.35 & +0.932 & +1.45 \\
\hline
\end{tabular}

*Without ascorbic acid.

Also, the effect of foreign compounds that may be present in dosage form were studied by adding different amounts of foreign substances to $100 \mu \mathrm{g} \mathrm{Bi}^{3+} / 25 \mathrm{ml}$.It was observed that the studied foreign species did not interfere in the present method Table (9). 
Table 9: Effect of interference (2).

\begin{tabular}{|c|c|c|c|}
\hline \multirow{2}{*}{ Interferences } & \multicolumn{3}{|c|}{$\begin{array}{c}\text { Recovery(\%) of 100 } \boldsymbol{\mu g} \text { Bi (III) / } \mathbf{\mu g} \text { of } \\
\text { Interferences }\end{array}$} \\
\cline { 2 - 4 } & $\mathbf{1 0 0}$ & $\mathbf{5 0 0}$ & $\mathbf{1 0 0 0}$ \\
\hline Starch & 98.6 & 97.0 & 96.0 \\
\hline Glucose & 97.5 & 100.0 & 98.1 \\
\hline Lactose & 103.6 & 100.7 & 101.6 \\
\hline Gum Arabic & 101.5 & 98.6 & 100.0 \\
\hline
\end{tabular}

\section{Application of the method}

Determination of $\mathrm{Bi}$ (III) in waters

The proposed method has been applied to the determination of bismuth (III) in various water samples, the results are shown in Table (10).

Table 10: Determination of Bi (III) in water samples.

\begin{tabular}{|c|c|c|c|}
\hline $\begin{array}{l}\text { Amount of } \\
\text { sample(ml) }\end{array}$ & Sample & $\begin{array}{c}\text { Bi (III) } \\
\text { added }(\mu \mathrm{g})\end{array}$ & Recovery $(\%)$ \\
\hline \multirow{3}{*}{$x_{1}=(2)$} & \multirow{9}{*}{ Tap water } & 25 & 103.8 \\
\hline & & 50 & 104.2 \\
\hline & & 100 & 104.9 \\
\hline \multirow{3}{*}{3} & & 25 & 101.0 \\
\hline & & 50 & 93.6 \\
\hline & & 100 & 105.2 \\
\hline \multirow{3}{*}{5} & & 25 & 105.4 \\
\hline & & 50 & 106.0 \\
\hline & & 100 & 101.3 \\
\hline \multirow{3}{*}{1} & \multirow{9}{*}{ Riverwater ${ }^{(a)}$} & 25 & 95.0 \\
\hline & & 50 & 107.8 \\
\hline & & 100 & 95 \\
\hline \multirow{3}{*}{3} & & 25 & 107.1 \\
\hline & & 50 & 96.3 \\
\hline & & 100 & 95.8 \\
\hline \multirow{3}{*}{5} & & 25 & 103.2 \\
\hline & & 50 & 93.3 \\
\hline & & 100 & 101.3 \\
\hline \multirow{3}{*}{1} & \multirow{9}{*}{ Well water ${ }^{(b)}$} & 25 & 103.2 \\
\hline & & 50 & 102.7 \\
\hline & & 100 & 96.8 \\
\hline \multirow{3}{*}{3} & & 25 & 95.6 \\
\hline & & 50 & 102.4 \\
\hline & & 100 & 97.6 \\
\hline \multirow{3}{*}{5} & & 25 & 103.8 \\
\hline & & 50 & 102.4 \\
\hline & & 100 & 100.4 \\
\hline \multirow{3}{*}{1} & \multirow{6}{*}{$\begin{array}{c}\text { Natural spring } \\
\text { water }^{(\mathrm{c})}\end{array}$} & 25 & 97.8 \\
\hline & & 50 & 95 \\
\hline & & 100 & 103.7 \\
\hline \multirow{3}{*}{3} & & 25 & 101.0 \\
\hline & & 50 & 104.8 \\
\hline & & 100 & 103.5 \\
\hline
\end{tabular}


Najih H. Shekho and Enas S. Thunoon

\begin{tabular}{|c|c|c|c|}
\hline $\begin{array}{l}\text { Amount of } \\
\text { sample(ml) }\end{array}$ & Sample & $\begin{array}{c}\text { Bi (III) } \\
\text { added }(\mu \mathrm{g})\end{array}$ & Recovery(\%) \\
\hline \multirow{3}{*}{5} & & 25 & 101.6 \\
\hline & & 50 & 97.5 \\
\hline & & 100 & 98.7 \\
\hline \multirow{3}{*}{1} & \multirow{9}{*}{$\begin{array}{c}\text { Rashidia } \\
\text { water }^{(\mathrm{d})}\end{array}$} & 25 & 93.0 \\
\hline & & 50 & 106.0 \\
\hline & & 100 & 95.8 \\
\hline \multirow{3}{*}{3} & & 25 & 95.6 \\
\hline & & 50 & 90.3 \\
\hline & & 100 & 93.6 \\
\hline \multirow{3}{*}{5} & & 25 & 103.2 \\
\hline & & 50 & 96.3 \\
\hline & & 100 & 102.4 \\
\hline \multirow{3}{*}{1} & \multirow{9}{*}{$\begin{array}{c}\text { Bekhaal } \\
\text { fallwater }^{(\mathrm{e})}\end{array}$} & 25 & 106.0 \\
\hline & & 50 & 103.0 \\
\hline & & 100 & 100.9 \\
\hline \multirow[t]{3}{*}{3} & & 25 & 105.4 \\
\hline & & 50 & 95 \\
\hline & & 100 & 100.3 \\
\hline \multirow{3}{*}{5} & & 25 & 104.3 \\
\hline & & 50 & 92.7 \\
\hline & & 100 & 101.0 \\
\hline
\end{tabular}

$\mathrm{a}=$ River water from Tigris river in Mosul city.

$b=$ Well water from Algubba near Mosul city

$\mathrm{c}=$ Natural spring water from life company.

$\mathrm{d}=$ River water from Al Rashidia region north Mosul city.

$\mathrm{e}=$ From Bekhaal region in Erbil city.

The results listed in Table (10) show that the method is successful for determining Bi (III) in the above water sample.

\section{Determination of Bi (III) in a veterinary preparation}

The proposed method has also been applied to the determination of $\mathrm{Bi}$ (III) in veterinary preparation. The results are listed in Table (11).

Table 11: Determination of Bi (III) in a veterinary preparation.

\begin{tabular}{|c|c|c|}
\hline \multicolumn{1}{|c|}{ Veterinary preparation } & $\mathbf{B i}^{\mathbf{3 +}}(\boldsymbol{\mu g})$ & Recovery*\% \\
\hline \multirow{2}{*}{$\begin{array}{c}\text { Diaclean }, 2000 \mathrm{mg} \\
\mathrm{Bi}\end{array}{ }_{5} \mathrm{O}(\mathrm{OH})_{9}\left(\mathrm{NO}_{3}\right)_{4} /$ Sachet, AVICO, Jordan } & 25 & 99.3 \\
\cline { 2 - 3 } & 50 & 102.2 \\
\hline
\end{tabular}

- Average of five determinations.

The above results reveal that the method is suitable for determining bismuth in the above sample with satisfactory recovery. Both the present method and the literature method (Marczenko, 2000) have been applied at the same time to t-test (Christian, 2004) and the value compared with the statistical tables for eight degrees of freedom at $95 \%$ validation 
level. The results in Table (12) show that there is no real difference between the two methods.

Table 12: The result of t-test.

\begin{tabular}{|c|c|c|c|c|}
\hline \multirow[b]{2}{*}{ Veterinary preparation } & \multirow[b]{2}{*}{$\mathrm{Bi}^{3+}(\mu \mathrm{g})$} & \multicolumn{2}{|c|}{ Recovery\%* } & \multirow[b]{2}{*}{ t. exp } \\
\hline & & $\begin{array}{l}\text { Present } \\
\text { method }\end{array}$ & $\begin{array}{l}\text { Literature method } \\
\text { (Marczenko,2000) }\end{array}$ & \\
\hline \multirow{3}{*}{$\begin{array}{l}\text { Diaclean } 2000 \mathrm{mgBi}_{5} \mathrm{O}(\mathrm{OH})_{9} \\
\left(\mathrm{NO}_{3}\right)_{4} / \text { Sachet }\end{array}$} & 25 & 99.3 & 99.6 & 0.032 \\
\hline & 50 & 102.2 & 100.2 & 0.060 \\
\hline & 100 & 98.3 & 96.4 & 0.83 \\
\hline
\end{tabular}

* Average of five determinations.

\section{Comparison of methods}

Table (13) shows the comparison between the analytical variables of the present method with those of other methods for bismuth determination.

Table 13: Comparison of method.

\begin{tabular}{|c|c|c|c|}
\hline $\begin{array}{l}\text { Analytical } \\
\text { Parameter }\end{array}$ & Present Method & $\begin{array}{l}\text { Literature Method* } \\
\text { (Afkami et al., 2006) }\end{array}$ & $\begin{array}{l}\text { Literature Method** } \\
\text { (Gaikwad et al., 2005) }\end{array}$ \\
\hline Reagent & $\begin{array}{l}\text { Bromopyrogallol } \\
\text { Red }\end{array}$ & Bromopyrogallol Red & $\begin{array}{l}\text { 1-amino-4,4,6-trimethyl } \\
(1 \mathrm{H}, 4 \mathrm{H}) \text { pyrimidine-2-thiol }\end{array}$ \\
\hline Surfactant & $\mathrm{CPC}+$ Triton X-100 & Triton X-114 & - \\
\hline pH & 3 & 3.8 & - \\
\hline Buffer & Glycine $-\mathrm{HCl}$ & Acetic acid - acetate buffer & - \\
\hline$\lambda_{\max }(\mathbf{n m})$ & 644 & 542 & 470 \\
\hline Beer's law rang & $0.12-6 \mathrm{ppm}$ & $4.60-120.0 \mathrm{ppb}$ & $7-24 \mathrm{ppm}$ \\
\hline $\begin{array}{c}\text { Molar } \\
\text { absorptivity } \\
\left(\operatorname{l.mol}^{-1} \cdot \mathbf{c m}^{-1}\right)\end{array}$ & $3.3 \times 10^{4}$ & 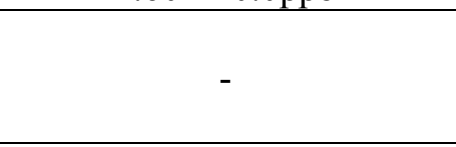 & $6.501 \times 10^{3}$ \\
\hline $\begin{array}{l}\text { Determination } \\
\text { coefficient }\left(\mathbf{R}^{2}\right)\end{array}$ & 0.999 & 0.998 & - \\
\hline LOD & $0.0462 \mu \mathrm{g} / \mathrm{ml}$ & $2.0 \mathrm{ng} / \mathrm{ml}$ & - \\
\hline LOQ $\mu \mathrm{g} / \mathrm{ml}$ & 0.0573 & - & - \\
\hline $\begin{array}{l}\text { Application of } \\
\text { the method }\end{array}$ & $\begin{array}{l}\text { Determination of } \\
\text { bismuth in water, } \\
\text { and veterinary } \\
\text { preparation }\end{array}$ & $\begin{array}{l}\text { Determination of bismuth in } \\
\text { human urine sample }\end{array}$ & $\begin{array}{l}\text { Determination of bismuth } \\
\text { in alloy samples }\end{array}$ \\
\hline
\end{tabular}

*Involves flash point extraction.

**Involves extraction in chloroform.

Comparatively, the present method is simple, sensitive and applicable to waters and veterinary preparation.

\section{CONCLUSION}

The proposed spectrophotometric method is simple, sensitive and low cost, it does not involve solvent extraction steps and gives precise and accurate results. The method has been applied successfully to the determination of bismuth in water samples and a veterinary preparation. 


\section{REFERENCES}

Afkami, A.; Madrakian, T.; Siampour, A. (2006). Cloud point spectrophotometric determination of trace quantities of bismuth in urine. J. Braz. Chem. Soc., 17 (4), 797-802.

Badgujar, DM.; Talawar, MB.; Asthana, SN.; Mahulikar, P. P. (2010). Synthesis and characterization of methyl nitramino 2, 4, 6 - trinitrobenzencs using bismuth nitrate penahydrate as an ecofriendly nitrating agent. J. Sci. Indu. Rese., 69(9), March, 208-240.

Banik, A. ; Batta, S. ; Bandyopahyay, D. ; Banik, B. K. (2010). Ahighy efficient bismuth catayzed rate for the synthsis of $\alpha$-amio-phosphorates. Molecules, 15, 8205-8213.

Christian, G. D. (2004). "Analytical Chemistry". 6th ed., John Wiley and Sons, Inc., New York, $90 \mathrm{p}$.

Delevic, R. (1997). "Principles of Quantitative Chemical Analysis". Mcgraw-Hill, International Ed., Singapore, 498p.

Demetrius, G. ; Themelis ; Parakevas, D. ; Tzanaras ; John, K. Papadimitrion (2001). Flow injection manifold for the direct determination of bismuth in phamacentical product using methylthymole blue as a chromogenic reagent. Analyst, 126, 247-256.

Gaikwad, S. H ; Mahamuni, S. V. ; Anuse, M. A. (2005). Extractive spectrophotometric determination of bismuth (III) in alloy sample using 1-amino-4, 4, 6-trimethyl $(1 \mathrm{H}$, 4H) pyrimidine-2-thiol. Indian J. Chem. Tech. 12, 365-368.

Hargis, L. G. (1988). "Analytical Chemistry, Principles and Tecliniques". Prentice-Hall International, London, pp. 424-427.

Marczenko, Z. (2000). "Spectrophotometric Determination of Elements". Ellis Horwood Ltd, Chichester, Chapter 10, pp. 114-120.

Oshita, K. ; Noguchi, O. ; Oshima, M. ; Motomizu, S. (2007). Synthesis of cross-linkad chitosan modified with the glycine oity per the cothection / concentration of bismuth in qguatic samples for ICP. MS determination. Anal. Sci., 23, 1203-1208.

Perrin, D. D. ; Dempsey, B. (1974). "Buffer for pH and Metal Ion Control". Chapman and Hall, Lte ; London, $131 \mathrm{p}$.

Rancic, S. ; Nikolic-Mandic, D. (2009). Kinetic spectrophotometric determination of Bi(III) based on its catalytic effect on the oxidation of phenyl florone by hydro peroxide. $J$. Serb. Chem. Soc. 74(8-9), 977-984

Reddy, D. V ; Reddy, A. V. (2010). Amperometric determination of bismuth using gallacetophenone phenyl hydrazone with the structural elucidation of complex. $E$. J. Chem., 7(4), 1290-1295.

Shi, J. ; Wang, X. ; Zhang, P. ; Zhu, H. ; Zhao, H. (2009). Determination of bismuth in hman by inductively coupled plasma-mass spectrometry and its use in bioequivalence studies. Asian J. Phar. Sci, 4(4), 228-233.

Thomas, D. W. (1991). "In Metal and their Compounds in the Environment". Merian, E., ed, $\mathrm{VCH}=$ Wienheim, pp. 789-801. 